\title{
HISTORICAL SKOLT SAMI MUSIC AND TWO TYPES OF MELODIC STRUCTURES IN LEU'DD TRADITION
}

\author{
Marko Jouste
}

\begin{abstract}
The Sami are an indigenous people living in Scandinavia, northern Fennoscandia, and the Kola Peninsula. The land of the Sami is located on the territories of Norway, Sweden, Finland, and Russia. Due to the fact that the Skolt Sami have always lived in a multicultural environment, their musical tradition is inherently multi-layered and the Skolt Sami have adopted a significant amount of shared traditions from the northeast of Russia into their own musical culture. However, the Skolt Sami have an indigenous musical genre called leu'dd, which is used to describe and comment on Skolt Sami life, both as 'history' and 'present', so that the leu'dds form a bank of shared memories of the Skolt Sami society. In my analysis I have presented an idea that there are two different types of melody structures in the historical material found from the archives. The model of fragmentary phrase structure explains many of the features found in the 'old type' leu'dd melodies, while the 'new type' can be understood through the idea that Russian and Karelian song melodies were used as the model for leu'dds.
\end{abstract}

Keywords: genres, leu'dd tradition, musical analysis, northeast Russia, oral history, phrase structure, Skolt Sami, traditional music

\section{THE EASTERN SAMI IN FINLAND AND RUSSIA}

The Sami are an indigenous people living in Scandinavia, northern Fennoscandia, and the Kola Peninsula. The land of the Sami is located on the territories of Norway, Sweden, Finland, and Russia. During the Middle Ages the Sami inhabited wide areas as compared to the present situation, covering considerably larger areas of modern Scandinavia and parts of north-western Russia. In historical sources, the Sami are often referred to as Phinnoi, Scrithifinoi, or Lapps. The current number of the Sami is estimated to be about 60,000 100,000 people. However, due to many centuries of forced assimilation in the abovementioned four countries, it is difficult to estimate the exact number of the Sami. In the Nordic countries there are national Sami Parliaments, which have a representative role in the administration of the Sami areas. In these countries there is also a system of schooling and higher education for the Sami (Lehtola 2015: 10; Sammallahti 2004: 168; Carpelan 1985: 36; 2002: 10). 
Historically, the Sami can be divided into several different groups according to language, source of livelihood, and the degree to which local environmental characteristics have influenced their cultures. In a historical and cultural sense, there is a pronounced difference between the Western and Eastern Sami. The Western Sami have had connections with Scandinavian and Finnish cultures and with the Lutheran Church. The eastern group, to which the Skolt Sami belong, is strongly influenced by Russian and Karelian cultures as well as the Orthodox Church. The Eastern Sami cultures in Russia can be divided into three main groups by the language and characteristics of culture. However, due to the radical cultural and social changes in this area especially during the Soviet era, definitions used here refer mainly to the cultural situation in the first half of the twentieth century. The traditional Ter Sami areas are located in the easternmost part of the Kola Peninsula. Kildin and Akkala Sami have inhabited the central part and Skolt Sami the westernmost part in the border area of Russia, Finland, and Norway. In Finland there are also the Aanaar Sami people, belonging to the Eastern Sami group (see Mustonen \& Mustonen 2011: 29-52; Jouste 2014: 361-362).

The Skolt Sami society was organised through the system of sijdds (Sami villages). A sijdd consisted of the inhabitants of a village and the area owned by them. There were some local and specific cultural characteristics in various sijdds. For example, the people of Suõ'nn'jel sijdd lived in an inland forest area, made their living by reindeer herding and lake-fishing, and had close contacts with the people of Inari. The neighbouring Peäccam sijdd was located on the mountainous shore of the Arctic Ocean and therefore sea-fishing was a natural source of income that supported reindeer herding. There was also a strong Russian element in their local culture, manifesting the influence of the Russian monastery nearby. There were seven sijdds in the Skolt Sami land in the early twentieth century. The farthest sijdd to the west was Njauddâm. It was the first to be separated from others when its area became a part of Norway in 1826, while Suõ'nn'jel, Paččjokk, Peäccam, Njuõ'ttjäu'rr, Mue'tǩk̆, and Sââ'rves were governed by Russia (Mustonen \& Mustonen 2011: 24-25; Linkola \& Linkola 2000: 130; Linkola \& Sammallahti 1995: 39-51; Jouste 2014: 361-362).

The early twentieth century Skolt Sami culture can be seen as essentially Skolt Sami but in the analysis one must take under consideration also the strong effect of the shared traditions of the neighbouring Karelian, Russian, Norwegian, and Finnish cultures since the traditional living areas of the Skolt Sami are located in a cultural melting pot of various northern peoples (Jouste 2014: 362-363; Laitinen 1977: 12-14; Pentikäinen 1971: 142). However, this multicultural environment, which had existed in this area for centuries, broke down during the twentieth century. Based on the Treaty of Tartu, the Skolt 
Sami territories were divided by the border between Finland and Russia in 1920. Saami village areas Paččjokk, Peäccam, and Suõ'nn'jel were incorporated into Finland and the area was named Petsamo. During the same period, the inhabitants of Njuõ'ttjäu'rr, Mue'ť̌k and Sââ'rves became Soviet citizens and they were forced to move elsewhere from their home areas during the 1930s. The contacts across the border began to decline and ceased to exist completely during and after the Second World War, when the Petsamo area was ceded to the Soviet Union. As Finnish citizens, the Skolt Sami of Petsamo decided to move to Finland permanently. The re-settling of the traditional living areas, which were now a part of the Soviet Union, would have been impossible. People were relocated to the new home areas of Njeä'llem and Če'vetjä'urr in Inari district (Linkola \& Linkola 2000: 158-167; Mustonen \& Mustonen 2011: 220-241). Today there are about 500 Skolt Sami in Finland and 1000 in Russia. The traditional culture of the Skolt Sami has suffered from forced migration during and after the Second World War. However, the Skolt Sami have been able to keep the traditional musical culture alive at least to some extent. Lately there has been a considerable local cultural revitalisation within the Aanaar Sami and Skolt Sami communities.

\section{GENRES OF THE TRADITIONAL SKOLT SAMI MUSIC}

Due to the fact that the Skolt Sami have always lived in a multicultural environment, their musical tradition is inherently multi-layered. Multiculturalism and influences from different musical traditions are visible in the diversity of musical genres described in the earlier research (see Laitinen 1977: 27-65; Saastamoinen 2000: 588-590; Jouste 2008: 24-28; 2011: 54). They are also found in the vast collection of archival material, gathered from the Skolt Sami during the twentieth century and preserved in archives in Finland, Russia, Sweden, Norway, and Estonia (see Jouste 2011: 54; Saastamoinen 2000: 96-97; 1998: 588-590). Furthermore, the researchers who visited the Skolt Sami area during the first decades of the twentieth century often made remarks about Karelian and Russian impact on the Skolt Sami culture. One of the most striking utterances was given by Armas Launis in 1922:

When I came to the Skolt Sami in the Petsamo region, I thought I would be visiting the same nomadic group of people who live in these areas. However, I did not find the Sami; I noticed that I had ended up in a place where people were Karelians. What else are the Skolt Sami than Karelians and especially brothers of Viena Karelians, both being descendants of ancient rich and mighty people of Perm. (Launis 1922: 28) ${ }^{1}$ 
There are various models for the Skolt Sami musical genre classification formulated in former research (Jouste 2006: 295-301; Saastamoinen 1998: 102-104; Laitinen 1977; 1981: 194-197; Paulaharju 1921: 194). The model presented here is based on the earlier ones as well as on my own research on the Skolt Sami archival material (see below).

In the centre of the Skolt Sami musical tradition is the genre of vocally performed individual song called leu'dd, which is essentially Skolt Sami. Sometimes there are leu'dds and songs (not connected with known members of the community) in fairy tales. A special genre found in the archival material is the use of voice in various signals, calling shouts for animals and imitations of the sounds that animals make. Other forms of musical expression belong to a group of traditions shared with north-western Russia. Many Skolt Sami songs from the early twentieth century have their stylistic origin in the neighbouring Russian or Karelian song traditions. This group includes secular songs (e.g. Karelian and Russian folk and dance songs), and Christian songs taken over from the Orthodox Church. Laments are found in the Eastern Sami musical traditions as well as those of Karelians and Russians, but not among the Sami living in Scandinavia. Skolt Sami lullabies often have baju-baju-syllables reflecting the link to Karelian and Russian lullaby tradition. There was instrumental dance music performed on accordions and harmonicas, as well as the vivid tradition of Karelian and Russian dances, e.g. the quadrille, sestjerkka, okkoldona, obsikruug, korobuska, oira, vintjorkka, vosmjorkka, krakoviacia, kerenski, and gemigorad (on Russian and Karelian impact see, e.g., Jouste 2013: 39-67; Häkämies 1978: 18-19; Nickul 1948: 57; Laitinen 1981: 195).

The main genres of the Skolt Sami musical tradition in the first half of the twentieth century are as follows:

1) Leu'dd tradition

a) Leu'dds of people

b) Leu'dds of nature and animals

c) Improvised leu'dds

2) Laments

3) Songs
a) Lullabies
b) Christian songs and hymns
c) Russian songs

4) Dance music
a) Dance songs
b) Instrumental music
(i.e. harmonica, accordion, gramophone) 
5) Songs and leu'dds in fairy tales

6) Other expressions by voice
a) Signals
b) Calling shouts for animals
c) Imitations of animal sounds

It is notable that singers vary songs and combine elements of different 'ideal' genres, and it is this process that creates new meanings in performances, and it is a central way of communication. The singers have knowledge of the functions of genres, they are aware of the genre system, which is further accompanied by a cultural code that directs the use of tradition. This kind of system articulated by performers in the Northern Sami yoik tradition is well documented but the conventions of the Skolt Sami musical tradition are far less known.

\section{LEU'DD AS A PART OF THE ORAL HISTORY OF THE SKOLT SAMI}

$L e u^{\prime} d d$ is a genre of unaccompanied Skolt Sami songs, and as a genre it has equivalents in other Eastern Sami individual song traditions, such as Kildin Sami luvvjt and Aanaar Sami livde. It is notable that the leu'dd tradition differs significantly from the Northern Sami luohti 'yoik', which is the most commonly known form of Sami music in the scientific literature. The Skolt Sami never use the term yoik when they refer to leu'dds although this kind of use of the term can occur in some older sources, when leu'dd is incorrectly translated into other languages.

With leu'dds singers refer to actual people, their life stories, and other historical events, and these can be studied in the broader context of local oral tradition. It can be defined as 'a history told by people's own voices' since leu'dds have preserved oral history over generations. In this way, the traditional Sami song differs also conceptually from the Western song tradition, in which the song texts often reflect more general subjects. Skolt Sami singers also comment on the various aspects of life inside the local community, and for this reason, leu'dds and the musical tradition in general are a valuable source of information about the Skolt Sami life and experience. Within this material it is possible to obtain a historical Skolt Sami perspective on their own history and individual and collective worldview (Jouste 2006; Jouste \& Mosnikoff \& Sivertsen 2007: 13-14).

During the performance of an individual song, the performer recalls the characteristics of a person and often his or her story. According to the cultural 
code, the song is 'owned' by its object and often also named after the latter. The performer leads the telling of the story by making allusions to the character of the subject or to some important events in his or her life. It is not often necessary to reveal everything about the character of the person, because it is expected that the participants or other listeners in the Sami society are acquainted with the person. According to Va'ss Semenoja, a Skolt Sami tradition bearer and performer, the "leu'dd is a description of the way someone has lived" (Jouste \& Mosnikoff \& Sivertsen 2007: 13).

Especially in the earlier times it was common that people knew each other's melodies. However, there was a rule that Skolt Sami singers did not perform a leu'dd when the object was present, avoiding a possible insult (Mosnikoff 2002; Itkonen 1991: 104). In addition to individual songs with specific people as a subject, there are many traditional songs of animals, nature, places, social events, etc., or songs referring more generally to various elements of the Skolt Sami society.

The first text example, O'lssee Piâtt leu'dd (see below), shows the way that a performer refers, with the text of a leu'dd, to the oral tradition and the historical events known in the Skolt Sami society. O'lssee Piâtt leu'dd was performed by Näskk Moshnikoff (neé Sverloff, 1893-1984) and during her visit in Helsinki in 1955 it was recorded by Erkki Ala-Könni. The text of the leu'dd refers to the story of how the Moshnikoff family became a member of the Suõ'nn'jel sijdd. The object of the leu'dd, O'lssee Piâtt Moshnikoff (1848-1909), was born into the Moshnikoff family in the Njuõ'ttjäu'rr sijdd in the middle of the nineteenth century. His father died when he was young, and he was adopted by his godfather Åls Gavriloff, who lived in the Suõ'nn'jel sijdd around the 1860s. As Åls Gavriloff did not have any children of his own, O'lssee Piâtt inherited the fortune and the traditional living area of Åls Gavriloff's family located in the Suõ'nn'jel sijdd. The words of the leu'dd describe the days of O'lssee Piâtt's youth. O'lssee Piâtt is the father of Peâtt-Huâttar, Peätt-Medrei, and PeättKiurel, who was the second husband of the performer Näskk Moshnikoff. The children of O'lssee Piâtt were born between 1877 and 1885, and his mother and grandmother are also mentioned in the text. There is also a tragic side to this story. O'lssee Piâtt died accidentally when he drove into open water on the ice of Lake Vuõlljääur in the spring of 1909. In the same accident died Näskk Moshnikoff's first husband, Karppa-Kiurel's son Huâttar (Gavriloff), whom she had married just a few months earlier (Nickul 1948: 36-37; Mosnikoff 2002; Jouste \& Mosnikoff \& Sivertsen 2007: 36). 
1. Kuäss mij-a vet jiâlažiim da At those times we lived,

2. Sââdd-a-žan O'lssee go källsaž. My father O'lsse

3. Njeeక̌žaž-am Feäđat nijdd. And my mother, Feäđat's daughter.

4. Pue'rr leäi-i, hää'š̌ jeä'll-e-ded Life was good

5. Õllgšjääu'r ääkka-laa. On the shore of Õll'šjääu'r.

6. Kü̈ss leäi Anisiag ääkka-laž. There was grandmother Anisiag.

7. kuäss leäi $\hat{a}^{\prime} l g \breve{g} \breve{g}$, hää'skes piârr- There were boys, there was a nice $a-a \check{z}$ family.

8. nijdd-a leäi vie'rpes piârr-agaž. There were daughters, a lively family.

9. Dohattõõssâž ä'ldd čiõkk-â-raž. There was a herd of a thousand reindeer.

10. Juuggadiim, poradiim We had good food

11. oocciisǩ eânai poottâlbeä'l. And sometimes we drank half a bottle.

(AK/0871; text transcription by Elias Mosnikoff and Seija Sivertsen)

\section{TWO TYPES OF MELODIC STRUCTURES IN LEU'DD TRADITION}

\section{Type 1: Fragmentary phrase structure}

During my research, I tentatively defined two different groups of melody types used in leu'dds. In the first type, the one-phrase or two-phrase melody is repeated iteratively throughout the performance, and each time the melody is performed with a new text line. However, the variants of different melody lines can differ so significantly from the melody line presented at the beginning of a leu'dd that in many cases it is difficult to define the 'original melody' and its variants as the same melody. This brings out the question of whether there are some rules for the variation or it is just free improvisation.

The fact is that the Skolt Sami tradition holders do recognize different leu'dds by their melodic features, and hence it cannot be a question of profoundly free musical expression. My suggestion is that many leu'dd melodies are modified in a special manner. I have defined this as a model of fragmentary phrase structure. The phrase itself is constructed out of several different melodic segments and an ending cadence, where the phrase always ends on the basic tone. It is typical that a leu'dd singer does not perform the whole melody on every repeat but 
chooses only some fragments of it before ending the phrase in a cadence. In the next repeat the singer may choose different melodic segments or even repeat some. The melody might occur in its full length a few times in a performance, but in most parts of the performance it is possible to hear only fragments of the full melody. With a paradigmatic structural analysis (see Niemi \& Jouste 2013) it is easy to visualize this full melody with all the possible melodic segments used in a particular leu'dd performance.

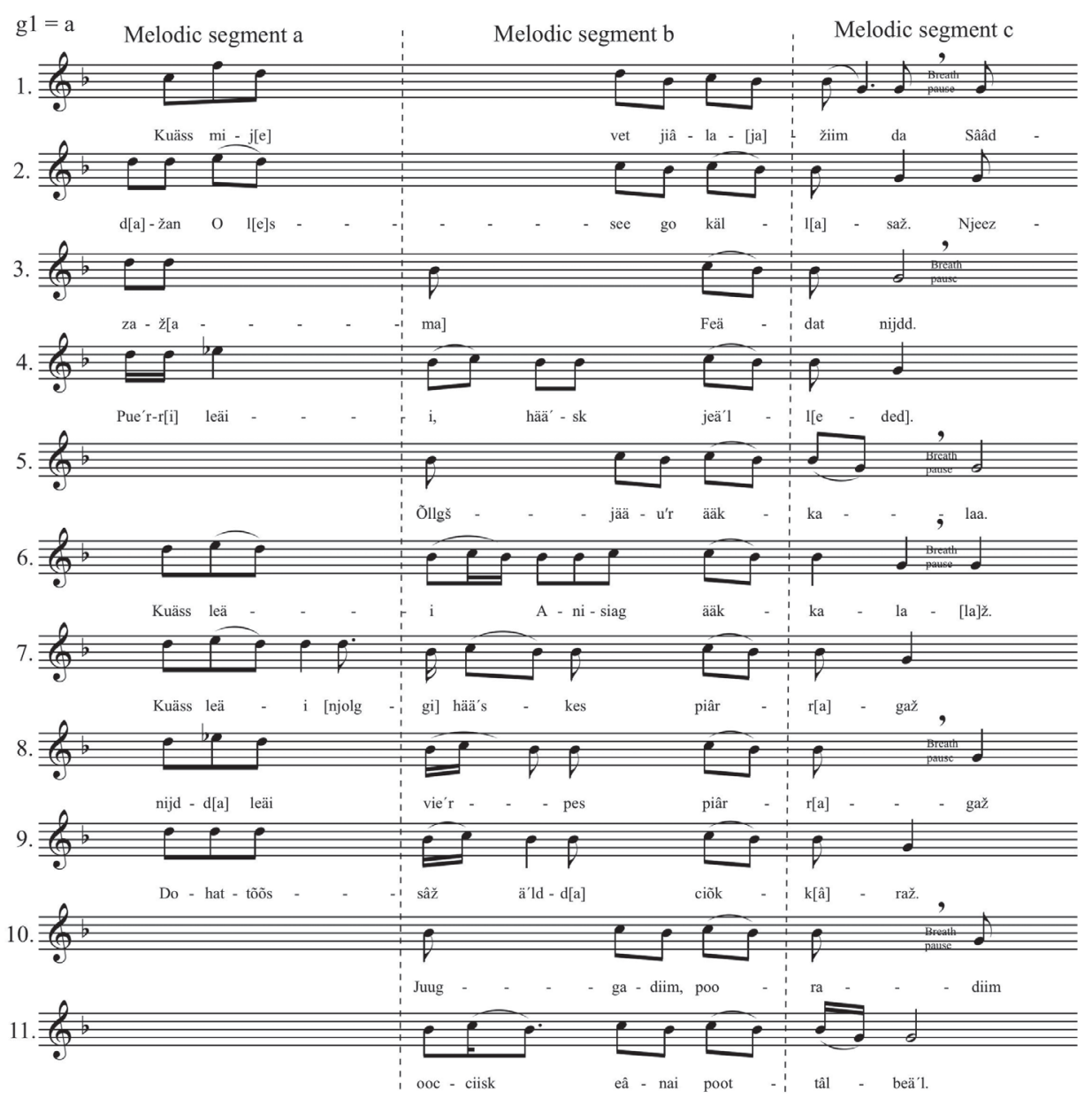

Figure 1. O'lssee Piâtt leu'dd. Performed by Näskk Moshnikoff in Helsinki in 1955. Folklife Archives, University of Tampere (AK/0871). Text transcription by Elias Mosnikoff and Seija Sivertsen. Musical transcription by Marko Jouste. 
The melody of Näskk Moshnikoffs O'lssee Piâtt leu'dd is performed with a fragmentary phrase structure. There are eleven melody lines and they differ from each other to some extent. The transcription of the whole performance is shown in Figure 1.

The melody of O'lssee Piâtt leu'dd consists of one phrase, which is repeated throughout the performance. Each time the melody is performed with a new text line, causing a different variation. It is important to notice that the rhythm of the melody is determined mainly by the rhythm of the text since leu'dds are unaccompanied and we can only occasionally hear a steady pulse in the performance. In order to clarify the analysis, it is better to distinguish the melodic and rhythmic layers and treat them separately in the analysis. In Figure 2, I have excluded the rhythm of the melody and analysed only the pitches of the melody and coded them by the numbers of their melodic degrees ( 1 equals basic tone, b3 equals minor third, etc.). The melodic segments found in the melody are marked with letters $\mathrm{a}, \mathrm{b}$, and c.

\begin{tabular}{|c|c|c|c|c|c|c|}
\hline Lines & Melodic & sme & & & & \\
\hline & $\mathbf{a}$ & $\mathbf{b}$ & & & & $\mathbf{c}$ \\
\hline 1. & $4-7-5$ & & & $5-\mathrm{b} 3$ & $4-b 3$ & b3 - 1 \\
\hline 2. & $5-6-5$ & & & $4-b 3$ & 4 - b3 & b3 - 1 \\
\hline 3. & 5 & b3 & & & $4-b 3$ & b3 - 1 \\
\hline 4. & $5-\mathrm{b} 6$ & b3 & & $4-b 3$ & 4 - b3 & b3 - 1 \\
\hline 5. & & b3 & & $4-b 3$ & 4 - b3 & b3 - 1 \\
\hline 6. & $5-6-5$ & b3 & & $4-b 3$ & $4-b 3$ & b3 - 1 \\
\hline 7. & $5-6-5$ & b3 & & $4-b 3$ & $4-b 3$ & b3 - 1 \\
\hline 8. & $5-\mathrm{b} 6-5$ & b3 & & $4-b 3$ & 4 - b3 & b3 - 1 \\
\hline 9. & 5 & b3 & & $4-b 3$ & $4-b 3$ & b3 - 1 \\
\hline 10. & & b3 & & $4-b 3$ & $4-b 3$ & b3 - 1 \\
\hline 11. & & b3 & $4-b 3$ & $4-b 3$ & $4-b 3$ & b3 - 1 \\
\hline
\end{tabular}

Figure 2. The analysis of the phrase structure of the melody in O'lssee Piatt leu'dd. The pitches are coded by the numbers of their melodic degrees; the melodic segments are marked with letters $a, b$, and $c$.

The analysis shows that every line is different from the others. A melodic segment can be repeated (see segment b in lines 1-2 and 8-9) or varied, and 
sometimes a segment is left totally out (see segment a in lines 5, 10, and 11). The basic 'rule' of creating a leu'dd melody in this manner could be summarized so that the first one begins from the upper part of the melody (here melodic segment a) and then descends slowly (here melodic segments b and c) to the basic tone, which is manifested by a cadenza (here melodic segment c). However, one cannot go back on the melody line; for example, you would not perform melodic segment a after melodic segment b.

The fragmentary phrase structure can be found both in one-phrase and two-phrase melodies. It is notable that among the Sami this kind of structure is found mainly in Eastern Sami music and especially in the Skolt Sami tradition. For example, the melodic structures of the Northern Sami luohti-tradition are clearly different (Laitinen 1981: 194; for comparative examples see Jouste 2006). There are also some interesting similarities between the fragmentary phrase structure of Skolt Sami leu'dds and some Viena Karelian joiku melodies (see, e.g., Kallberg 2004), but this topic requires further research.

\section{Type 2: Leu'dds with song-like melodies}

In the second type of leu'dds the overall idea is that many of the song-like melodies might have a melodic model taken from the song traditions of the neighbouring peoples (for more examples see Jouste 2013). This can be seen in the next example of the leu'dd Miklai da Tädjjan. It was performed by Va'ss Semenoja in Kirakkajoki, during a field recording organised by the Finnish Broadcasting Company in 1961. Since the performance is rather long, lasting 4:45 minutes, I only present here an excerpt of the melody. The melody consists of three phrases and the phrase structure is abb. This is repeated throughout the performance but so that all melody lines clearly resemble each other. The basic melody does not vary in a manner that it would if it were an example of the fragmentary phrase structure. There is some variation also in this type, especially in the rhythm, caused by different words in different text lines.

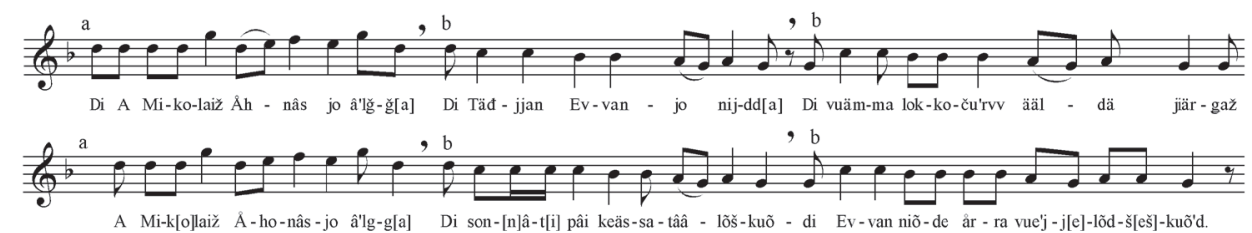

Figure 3. An excerpt of Miklai da Täđjjan performed by Va'ss Semenoja in 1961. University of Tampere, Folklife Archives, AK/0563. Text transcription by Elias Mosnikoff and Seija Sivertsen. Musical transcription by Marko Jouste. 
The melodic model for this leu'dd comes from a Russian sailor's song called Iablochko ('small apple'), which was pointed to me by a Russian musicologist Mikhail Lobanov. He transcribed the following melody from memory after having heard the recording. The Iablochko melody is also known as a Russian sailors' dance, and it became widely known during the First World War (Zemtsovsky 2001: 9; Jouste 2013: 59-57; http://worldorch.pbworks.com/w/ page/15428653/Russian\%20Sailor\%27s\%20Dance). The Iablochko melody also has abb-structure, with the first phrase moving in the upper register, followed by a descending phrase repeated twice. One can easily notice the similarity between these two examples (see Fig. 4).

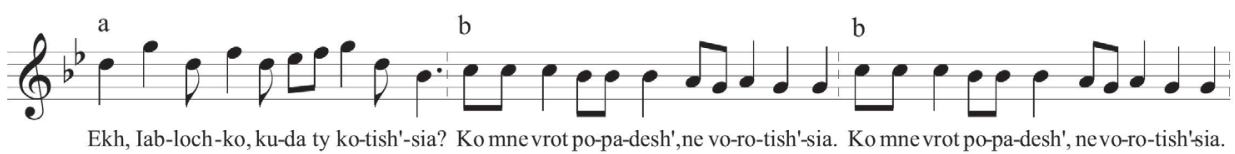

Figure 4. Iablochko melody. Transcription from memory by M. Lobanov in possession of the author.

An interesting question is whether there are any clues of how and when these song melodies were incorporated into the leu'dd tradition of the Skolt Sami. Naturally, there is the general notion of multiculturalism and influences from different musical traditions in the cultural melting pot in the western part of the Kola Peninsula. There is also well-documented historical data of how Skolt Sami men, who were recruited into the Russian army during the First World War, learned songs during their service and when they returned, the new songs and melodies became a new fashionable part of the Skolt Sami music (Launis 1922: 30). One of the most famous Skolt Sami life stories including the war period is that of Jääkk Sverloff, who became the head of the Skolt Sami community during post-war decades (see Ingold 1976: 235-253; Linkola 1985: 99). Among the present Skolt Sami, Jääkk Sverloff and also Olli Gauriloff have the reputation of introducing many of these Russian musical influences and new dances to the people of the Suõ'nn'jel sijdd after they returned from the war in the early 1920s (SKNA, 09842/a).

These influences can be heard also in other Skolt Sami musical genres. For example, a variant of the same Iablochko-melody is found in a quadrille dance song Mâid kuulak-a niõd-e ju určči juugg-u-de-ja? ('What are you youngsters running for?'), performed by Jääkk Sverloff. In this variation the repeated b-phrase is shortened as compared to the previous example of the Iablochkomelody (see Figs. 4 \& 5). 


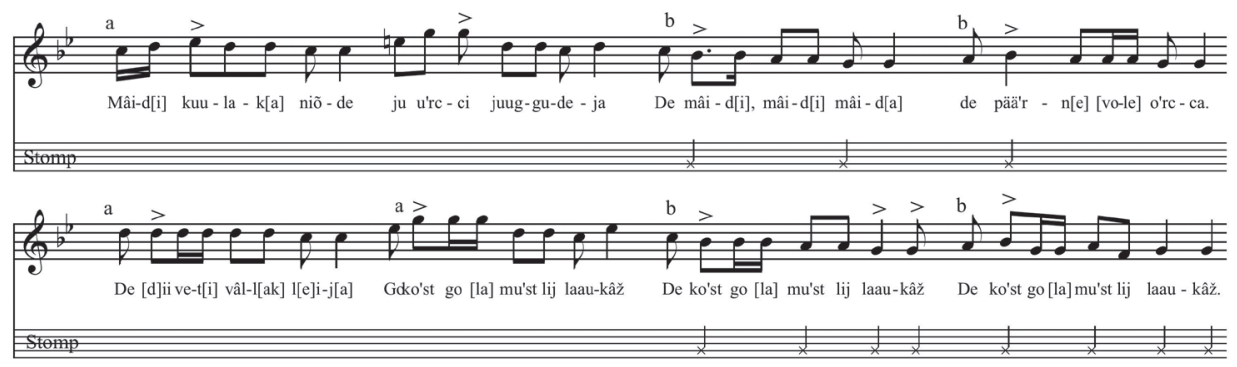

Figure 5. Mâid kuulak-a niõd-e ju určči juugg-u-de-ja? ('What are you youngsters running for?'). Performed by Jääkk Sverloff. University of Tampere, Folklife Archives, AK/ 0568. Text transcription by Elias Mosnikoff and Seija Sivertsen. Musical transcription by Marko Jouste.

Finally, it is also interesting to mention that Finnish researcher Armas Launis, who undertook fieldwork in the Skolt Sami area in 1922, also mentions two separate styles of leu'dds during his visit. Launis gathered altogether 60 wax cylinder recordings and transcribed 173 melodies from the Skolt Sami of Suốnn'jel and Paččjokk. He wrote about two leu'dd singers with different styles, who both lived in the Paččjokk sijdd. Launis described these styles, though his views contain evaluations somehow typical of the early twentieth century musicology, and also connected with Launis' own 'literate' or 'sophisticated' musical taste. According to Launis, Evvan Råmman (Romman Ofanasief, 1852-) used the old melody type and his style differed from the more popular style of the 1920s. His melodies were simple, non-ornamented, monotonic, and robust, composed in the old-fashion Sami style. However, his repertoire of this kind of melodies was notable. The other leu'dd singer was Mihkel-Vää'sǩ O'nddri (in the original: Mihkel-Vask Ondrei, 1854-) and he was known as a composer of leu'dds in the new style. Launis described that his melodies sounded richer with broader and modern motifs, and possessed a different tempo, so they sounded interesting to him as compared to Evvan Råmmans' melodies. Launis also writes that it is no wonder that the Skolt Sami prefer these melodies and that this is why they have spread all over the area where Finnish Skolt Sami live (Launis 1922: 30, 35-36). 


\section{CONCLUSION}

In all the periods from which we have historical sources, we can see that there have been cultural contacts between different peoples in the northeast of Russia and Scandinavia. It is notable that the Skolt Sami have adopted a significant amount of shared traditions from the northeast of Russia into their own musical culture and also into culture on a more general level. These Russian, Karelian, Norwegian, and Finnish songs were performed in their original form, but sometimes melodies and other musical features were incorporated into traditional music, resulting in a unique, diverse, and multi-layered musical culture.

The leu'dd tradition was used to describe and comment on Skolt Sami life, both as 'history' and 'present', so that the leu'dds form a bank of shared memories of the Skolt Sami society. In my analysis I have presented the idea that there are two different types of melody structures in the historical material found from the archives. The model of fragmentary phrase structure explains many of the features found in the 'old type' leu'dd melodies, while the 'new type' can be understood through the idea that Russian and Karelian song melodies were used as the model for leu'dds. The study of historical Skolt Sami musical culture shows how a strong local culture can also take influences from other cultures without losing its own characteristics and identity.

\section{NOTES}

1 Translated by the author.

\section{ARCHIVAL SOURCES}

AK/0871 - Folklife Archives, University of Tampere. O'lssee Piâtt leudd performed by Näskk Moshnikoff in Helsinki in 1955.

AK/0568 - Folklife Archives, University of Tampere. Mâid kuulak niõđ ju určči juuggdeja, performed by Jääkk Sverloff in 1961.

AK/0563 - Folklife Archives, University of Tampere. Miklai da Tädjjan, performed by Va'ss Semenoja in 1961.

SKNA 09842/a - Institute for the Languages of Finland, Helsinki (Kotus). Interview of Tatjana Killanen with Mikko Korhonen in Sevettijärvi, Finland, in 1971. 


\section{INTERNET SOURCES}

http://worldorch.pbworks.com/w/page/15428653/Russian\%20Sailor\%27s\%20Dance, last accessed on January 31, 2017.

\section{REFERENCES}

Carpelan, Christian 1985. Saamelaisten esihistoriaa ja saamelaisargeologiaa. [The Prehistory and Archaeology of the Sami.] In: Martti Linkola (ed.) Lappi 4: Saamelaisten ja suomalaisten maa. Hämeenlinna: Karisto Oy, pp. 36-37.

Carpelan, Christian 2002. Arkeologiset löydöt aikaportaina. [Archaeological Findings as Time-Gates.] In: Riho Grünthal (ed.) Ennen muinoin: Miten menneisyyttämme tutkitaan. Tietolipas 180. Helsinki: Suomalaisen Kirjallisuuden Seura, pp. 188212. Available at https://helda.helsinki.fi/handle/10224/3522, last accessed on January 31, 2017.

Häkämies, Irja 1978. Kolttasaamelainen musiikkiperinne. [The Musical Tradition of the Skolt Sami.] Kansanmusiikki, No. 2, pp. 16-21.

Ingold, Tim 1976. The Skolt Lapps Today. Changing Cultures. Cambridge: Cambridge University Press.

Itkonen, Toivo Immanuel 1991. Lapin-matkani. [My Travels to Lapland.] Porvoo: WSOY. Jouste, Marko 2006. Suomen saamelaisten musiikkiperinteet. [The Musical Traditions of the Sami in Finland.] In: Anneli Asplund \& Petri Hoppu \& Heikki Laitinen \& Timo Leisiö \& Hannu Saha \& Simo Westerholm (eds.) Suomen kansanmusiikin historia: Kansanmusiikki. [The History of the Finnish Music: Finnish Folk Music.] Helsinki: WSOY, pp. 272-307.

Jouste, Marko 2008. Venäläisen bylinan ja kolttasaamelaisen leuddin välisestä yhteydestä. [A Link between Russian Bylina and Skolt Saami Leu'dd.] Musiikin suunta, Vol. 3-4. Helsinki: Suomen etnomusikologinen seura, pp. 11- 31.

Jouste, Marko 2011. Katsaus koltan- ja kuolansaamelaisiin musiikkiperinteisiin. [A Review of the Skolt and Russian Sami Musical Traditions.] In: Pekka HuttuHiltunen \& Janne Seppänen \& Frog \& Eila Stepanova \& Riikka Nevalainen (eds.) Sommelon säikeitä: Runolaulu-Akatemian seminaarijulkaisu 2009-2010. [Threads of Sommelo: Proceedings of the Runosong Academy Seminar.] Juminkeon julkaisuja, No. 86. Kuhmo: Juminkeko, pp. 51-74.

Jouste, Marko 2013. Lampaitako olette, kun ette osaa edes katrillia tanssia? Venäläisen musiikkikulttuurin vaikutuksia historiallisessa Suonikylän musiikkiperinteessä. [Are You Sheep, You Can't Even Dance the Quadrille? The Impact of Russian Music Culture in the Historical Musical Tradition of Suõ'nn'jel Sijdd.] In: Pekka Huttu-Hiltunen \& Mirja Kemppinen \& Maari Kallberg \& Sari Karikko (eds.) Laulu inhimillisen kommunikaation muotona. [Song as a Form of Human Communication.] Proceedings from the Runosong Academy Seminar, 23-25 March 2012. Kuhmo: Juminkeko, pp. 39-67. Available at http://www.academia.edu/ Documents/in/Saami_Culture_and_Literature, last accessed on January 31, 2017. 
Jouste, Marko 2014. Katsaus Venäjän saamelaisten musiikkiperinteiden keräykseen ja tutkimukseen. [A Review of the Study and Gathering of the Russian Sami Musical Traditions.] In: Pekka Huttu-Hiltunen \& Frog \& Karina Lukin \& Eila Stepanova (eds.) Song and Emergent Poetics. Runolauluakatemian julkaisuja, No. 18, Juminkeon julkaisuja, No. 119. Kuhmo: Juminkeko, pp. 361-394.

Jouste, Marko \& Mosnikoff, Elias \& Sivertsen, Seija 2007. Maaddâr ää'jji lee'ud: Historiallisia kolttasaamelaisia leu'ddeja. [The Leu'dds of the Ancestors: Historical Skolt Sami Leu'dds.] CD and booklet. Inari: Saamelaismuseosäätiö \& KansanmusiikkiInstituutti \& Kolttien kyläkokous.

Kallberg, Maari 2004. A. O. Väisänen ja Miitrelän Ilja: Vienankarjalaisten joikujen piirteitä. [A. O. Väisänen and Ilja Miitrelä: The Characteristics of Viena Karelian Joiku Tradition.] Kuhmon musiikkiopiston julkaisuja, No. 4. Kuhmo: Kuhmon kaupunki/musiikkiopisto.

Laitinen, Heikki 1977. Suonikylän laulut vuonna 1961: Tutkielma kolttasaamelaisten musiikkiperinteestä. [The Songs of Suõ'nn'jel Sijdd in 1961: A Study of Skolt Sami Musical Tradition.] MA Thesis. Helsinki: Helsingin yliopiston musiikkitieteen laitos.

Laitinen, Heikki 1981. Saamelaisten musiikki. [The Music of the Sami.] In: Anneli Asplund \& Matti Hako (eds.) Kansanmusiikki. [Folk Music.] Suomalaisen Kirjallisuuden Seuran toimituksia 366. Helsinki: Suomalaisen Kirjallisuuden Seura, pp. 179-198.

Launis, Armas 1922. Kaipaukseni maa: Lapinkävijän matkamuistoja. [The Land of My Longing: The Diary of a Visitor in Lapland.] Jyväskylä: Gummerus.

Lehtola, Veli-Pekka 2015. Saamelaiset: Historia, yhteiskunta, taide. [The Sámi People: History, Society, Art.] Inari: Kustannus-Puntsi.

Linkola, Martti 1985. Jaakko Sverloff. In: Martti Linkola (ed.) Lappi 4: Saamelaisten ja suomalaisten maa. Hämeenlinna: Karisto Oy, p. 99.

Linkola, Anni \& Linkola, Martti 2000. Kolttasaamelaiset: Vähemmistön vähemmistö. [The Skolt Saami: The Minority of a Minority.] In: Jukka Pennanen \& Klemetti Näkkäläjärvi (eds.) Siiddastallan: Siidoista kyliin. Luontosidonnainen saamelaiskulttuuri ja sen muuttuminen. Inarin saamelaismuseon julkaisuja 3. Jyväskylä: Pohjoinen, pp. 158-167.

Linkola, Martti \& Sammallahti, Pekka 1995. Koltanmaa - osa saamenmaata. [The Skolt Sami Land.] In: Tuija Saarinen \& Seppo Suhonen (eds.) Koltat, karjalaiset ja setukaiset: Pienet kansat maailmojen rajoilla. [Skolt Sami, Karelians, and Setus: Small Nations on the Borders of the World.] Snellman-instituuttin A-Sarja 19. Kuopio: Snellman-instituutti, pp. 39-57.

Mosnikoff 2002 = Elias Mosnikoff. Personal interview. Tampere, January 21, 2002.

Mustonen, Tero \& Mustonen, Kaisu 2011. Eastern Sámi Atlas. Vaasa: Snowchange.

Nickul, Karl 1948. The Skolt Lapp Community, Suenjelsijd, During the Year 1938. Nordiska Museet: Acta Lapponica V. Stockholm: Hugo Gebers Förlag.

Niemi, Jarkko \& Jouste, Marko 2013. Musiikin paradigmaattinen analyysi. [Paradigmatic Music Analysis.] In: Pirkko Moisala \& Elina Seye (eds.) Musiikki kulttuurina. [Music as Culture.] Suomen Etnomusikologisen Seuran julkaisuja 21. Helsinki: Suomen Etnomusikologinen Seura, pp. 173-200. 
Paulaharju, Samuli 1921. Kolttain mailta: Kansatieteellisiä kuvauksia KuollanLapista. [From the Lands of the Skolt Sami: Ethnographic Descriptions from Kola Lapland.] Helsinki: Kustannusosakeyhtiö. Available at http://www.doria. fi/handle/10024/59678, last accessed on January 31, 2017.

Pentikäinen, Juha 1971. Lappalaisten perinnealuejako. [The Areal Division of Folklore Genres of the Sami.] In: Hannes Sihvo (ed.) Vanhaa ja uutta Lappia. Kalevalaseuran Vuosikirja 51. Porvoo \& Helsinki: Söderström, pp. 127-146.

Saastamoinen, Ilpo 1998. Laulu - puu - rumpu: Saamelaismusiikin alkulähteillä. [Song - Tree - Drum: At the Springs of Sami Music.] Licentiate study in musicology. Jyväskylä: Jyväskylän yliopisto. Available at https://jyx.jyu.fi/dspace/ handle/123456789/9982, last accessed on January 31, 2017.

Saastamoinen, Ilpo 2000. Itäsaamelaisten musiikkiperinteestä. [The Music Tradition of the Eastern Sami.] In: Irja Seurujärvi-Kari (ed.) Beaivvi mánát: Saamelaisten juuret ja nykyaika. [The Roots and Today of the Sami.] Tietolipas 164. Helsinki: Suomalaisen Kirjallisuuden Seura, pp. 83-122.

Sammallahti, Pekka 2004. Saamelaisten juuret. [The Origins of the Sami.] In: Riho Grünthal (ed.) Ennen muinoin: Miten menneisyyttämme tutkitaan. Tietolipas 180. Helsinki: Suomalaisen Kirjallisuuden Seura, pp. 159-173.

Zemtsovsky, Izaly 2001. Russian Federation. II. Traditional music. 1. Russian. In: Stanley Sadie (ed.) The New Grove Dictionary of Music and Musicians, Vol. 22, 2nd edition. London: Macmillan, pp. 1-10.

Marko Jouste works at the Giellagas Institute at University of Oulu, Finland, as a researcher, teacher, and developer of the Saami Culture Archives. He received his $\mathrm{PhD}$ degree in 2011.

marko.jouste@oulu.fi 